\begin{tabular}{|c|c|c|}
\hline $\begin{array}{l}\text { INESEG } \\
\text { INTERNATIONAL } \\
\text { ENGINEERING } \\
\text { SCIENCE AND } \\
\text { EDUCATIONGROUP }\end{array}$ & $\begin{array}{c}\text { International Journal of Health Services } \\
\text { Research and Policy } \\
\text { www.dergipark.org.tr/ijhsrp } \\
\text { e-ISSN: } 2602-3482\end{array}$ & IJHSRP \\
\hline
\end{tabular}

Review Article

\title{
PERIOPERATIVE NURSING CARE IN CASES REQUIRING EMERGENCY SURGERY IN COVID-19 INFECTED PATIENTS
}

\section{Remziye CICI iDI Esra ANUŞ TOPDEMIR (D) ${ }^{2}$}

${ }^{1}$ Hitit University, Faculty of Health Sciences, Department of Nursing, Çorum, Turkey.

${ }^{2}$ Dicle University, Ataturk School of Health, Department of Nursing, Diyarbakır, Turkey

* Corresponding author: remziyecici@ hotmail.com

\begin{abstract}
Covid-19 which emerged in Wuhan, China in December 2019, is an infectious disease caused by coronavirus and causes serious respiratory infections. The Covid-19 disease was declared as a pandemic by the World Health Organization in March 2020 due to its easy and rapid spread and affecting many countries globally. This rapid spread also increased the number of individuals infected with the virus worldwide. Unfortunately, deaths resulting from the disease cannot be prevented and the number of individuals who lost their lives continues to increase rapidly. Elective surgery of individuals who are infected or at risk can be postponed in pandemics with such a high rate of infectiousness and disease-related mortality. However, if the absence or postponement of the surgery is life-threatening, performing the surgery becomes inevitable. An individual infected or possibly infected with the Covid19 virus may pose many risks during the surgical procedure, which requires taking some additional precautions before, during, and after surgery. In addition to the normal surgical process, perioperative nursing care should focus on some specific issues during the pandemic, which is improving the treatment success of the patients, improving the quality of the care, ensuring that the Covid-19 disease is overcome without complications, and preventing the transmission of the disease to other individuals. Thus, the perioperative nursing care of the Covid-19 patients with the possible or definitive diagnosis was discussed considering the available literature.
\end{abstract}

Keywords: Covid-19, Nursing, Nursing Care, Perioperative Care

Received: June 7, $2020 \quad$ Accepted: November 24, 2020

\section{Introduction}

Covid-19 emerged in Wuhan, China in December 2019 as a disease of unknown cause and transmitted from person to person. This disease caused pneumonia and did not respond to treatments [1-3]. It spread rapidly in late January 2020 and started to cause epidemics in many different countries. For this reason, the Covid-19 disease was declared as a pandemic by the World Health Organization (WHO) in March [4].

The Covid-19 virus is transmitted through the spread of droplets from sick individuals' coughing or sneezing [4, 5]. It is stated that the virus can live 4 hours in the copper [2], 24 hours in cardboard [2], 
24 hours in cloth [6], 24 hours in the wood [6], 4-7 days in plastic and stainless steel [2,6], and 2 days in glass [6]. When individuals touching the surfaces infected with the Covid-19 virus take their hands to the mouth, nose, or eye mucosa, the disease is transmitted [4,5]. The Coronavirus is generally not known to be very resistant to the external environment [4]. Therefore, the activity and life span of the Covid19 virus in the external environment vary depending on the humidity and temperature of the environment, the amount of organic matter it is discharged from, and the texture of the contaminated surface. This information reveals that the lifespan of the virus and the individual's contact duration with the virus are also important in the contagiousness of the disease $[4,5]$.

It has been reported that the general incubation period of the Covid-19 virus is 2- 14 days, mostly 5-6 days [5, 7], however, in some cases, there is a viral eruption time of 37 days [1]. Although the infection period of the virus is not known precisely, it is thought that it starts 1-2 days before the symptoms develop and ends with the disappearance of the symptoms [4]. The symptoms of the disease are fever, dry cough, and dyspnea [1, 8, 9]. In approximately half of the patients, the symptoms may be mild enough to be ignored [10]. In more serious cases, pneumonia, acute respiratory failure syndrome, sepsis, metabolic acidosis, coagulation dysfunction, kidney failure and even death (the fatality rate of Covid19 is $3.8 \%$ ) can be observed $[4,5]$.

In the world, the number of individuals who came into contact with this virus and got sick, and the number of individuals who died has been increasing rapidly [11]. In severe pandemic situations that spread rapidly and cause deaths, elective surgeries can be postponed. However, the situation is different in an emergency (such as intestinal obstruction, kidney or ureteral obstruction that cannot be delayed more than 24-48 hours) or very urgent (such as gunshot wound or stab wound requiring immediate intervention and aortic aneurysm). If there is a life-threatening situation when surgery is not performed, surgery cannot be delayed and it becomes a surgical obligation [12]. It is necessary to increase the success of treatment of patients who are planned to have surgery due to an emergency, to improve the quality of care, and to prevent the transmission of the disease to other individuals (other patients, healthcare workers). Therefore, good planning is required for preoperative preparation and postoperative care. This is possible with team collaboration and good nursing care. In this study, information about the nursing care provided for the patients with a possible or definitive Covid-19 diagnosis before, during, and after surgery is given.

\section{Preoperative Preparation Period of a Covid-19 Patient}

The patient, who is scheduled for emergency surgery, may be an asymptomatic patient or a patient with a definitive Covid-19 diagnosis. For this reason, surgical nurses feel under considerable pressure during the preoperative period.

\subsection{Preoperative Patient Evaluation}

Nurses should act according to droplet and contact isolation methods at every stage of the preoperative process and every contact with the patient. Personal Protective Equipment (PPE) must be used within the scope of the measures to be taken (Table 1) $[3,8,13]$. The personal protective equipment should be worn in accordance with the rules and in the order of gowns, masks, bonnets, goggles, face protectors, and gloves $[3,8,13]$. The nurse to be in contact with the patient should wear the PPE in a specially reserved room [10]. The nurse should leave all his/her belongings in this room, tie his/her 
hair up, put the upper part of his/her uniform inside the pants, and disinfect his/her hands. Shoes must be made of non-perforated and sterilizable material and fully cover the feet and ankles. The legs of the surgical gown should be inserted into the shoes, and then a waterproof apron should be worn. Even specially prepared protective overalls can be used. After a bonnet is worn to cover the head and neck, a protective mask (surgical mask, N95/FFP2 or N99/FFP3), which is determined according to the procedure to be performed with the patient, is worn. Then, goggles or face protective transparent barriers (screen), and finally gloves are worn. After the preparation is completed, the shortest path is followed without touching the items in the room and the nurse enters the patient's room $[3,4,10,13]$.

Table 1. Personal Protective Materials Required for Personnel Who will Contact Possible/Definitive Covid-19 Cases at a Distance Less than one Meter

\begin{tabular}{|c|c|}
\hline Material & Characteristics \\
\hline Gloves & $\begin{array}{l}\text { Non-sterile (sterile gloves can be used according to the process } \\
\text { to be performed) }\end{array}$ \\
\hline Gown or overall & $>$ Preferably water-proof and long-sleeved \\
\hline Bonnet & $>$ \\
\hline Mask & $\begin{array}{l}\text { Surgical mask } \\
\text { N95/FFP2 or N99/FFP3 mask: Only for processes that produce } \\
\text { droplets/ aerosolization such as aspiration, bronchoscopy, and } \\
\text { bronchoscopic procedures, intubation, taking the respiratory } \\
\text { sampling }\end{array}$ \\
\hline Face protective & $>$ \\
\hline $\begin{array}{l}\text { All face respiration } \\
\text { protective equipment } \\
\text { or motor-operated air } \\
\text { cleaner respirator }\end{array}$ & $\begin{array}{l}\text { In operations such as tracheal intubation, tracheotomy, } \\
\text { broncho-fibro scope, and gastroenterological endoscopy as } \\
\text { possible or validated patient can spray or splash respiratory } \\
\text { secretion, blood or body fluid } \\
\text { While healthcare personnel is performing the operation or } \\
\text { autopsy of the patient who possibly has the virus or confirmed } \\
\text { to have the virus. } \\
\text { While the personnel is running Covid-19 nucleic acid test }\end{array}$ \\
\hline
\end{tabular}

\subsection{Physical assessment}

It is very important to obtain accurate and detailed information about the patient in the preoperative period. Thus, the nurse should take a detailed history. However, a safe environment must be established to protect the patient and himself/herself [11]. The patient must be kept in an isolated room (Table 2) and the nurse must enter the patient's room dressed in PPE [3, 13]. During this period, a detailed history should be obtained from the patient and/or their relatives, and factors that may pose a risk during surgery should be evaluated. The patient's age, job, place of residence, chronic diseases, past surgical experience, history of allergy, medications, substance use, and history of all body systems should be included in the history [12]. 
Table 2. Features of the Patient Room and Rules to be followed in the Room

$>$ Standard, contact, and droplet isolation methods should be applied during the hospitalization of individuals with possible or definitive diagnosis of Covid-19.

$>$ The patient should be treated in a single room with a bathroom and toilet.

$>$ In cases when single rooms are not available, patients with Covid-19 definitive diagnosis can be cohort in the same room.

It is preferable to treat potential Covid-19 patients in separate rooms.

$>$ In compulsory cases, potential Covid-19 patients can be in the same room. However, they should be at least 1 meter apart.

$>$ Potential Covid-19 patients in the same room should wear a medical mask during hospitalization.

$>$ Medical materials to be used for diagnosis, treatment, or care of patients should be patientspecific and should not be taken out of the room.

Patients should not be allowed to use the same materials.

$>$ If the equipment to be used (e.g. stethoscope, fever meter) should be used in more than one patient, the tools should be cleaned and disinfected after each use (e.g. ethyl alcohol 70\%).

$>$ Unless medically necessary, patients should not be moved from their environment to another environment.

$>$ Portable devices designated for potential Covid-19 patients should be used (X-ray device and/or other important diagnostic devices).

$>$ If there are no portable diagnostic devices, the patient should be taken, if possible, as the last case in accordance with contact and droplet isolation methods and wearing a medical mask, minimizing contact with other patients and visitors.

$>$ Health personnel involved in the transportation of the patient should wear medical masks, gowns, and gloves and pay attention to hand hygiene.

$>$ N95 / FFP2 or N99 / FFP3 mask and goggles should be present next to the patient if the patient has a condition that may cause aerosolization according to the general condition of the patient.

$>$ All surfaces that the patient touches should be cleaned and disinfected regularly.

$>$ Patient rooms should be cleaned and disinfected based on the rules determined in accordance with the directives of the infection control committees.

$>$ To dispose of used personal protective equipment and other wastes, two separate medical waste bins should be kept at the entrance of the patient room and inside the patient room.

The data required to evaluate the patient's condition and to compare changes before and after the intervention should be obtained during this period. The patient's vital signs should be measured and recorded. Necessary diagnosis and laboratory tests should be performed and the results obtained should be documented correctly [12]. Patients with Covid-19 poor prognosis have been reported to have a high Sequential Organ Failure Assessment (SOFA) score [1]. Therefore, if the patient is unconscious or is in the intensive care unit, the necessary scoring systems must be applied. Besides, patients with Covid-19 poor prognosis are reported to have d-dimer levels higher than $1.0 \mu \mathrm{g} / \mathrm{Ml}$ [1]. Therefore, this value should also be checked in laboratory tests.

\subsection{Psychological assessment and pre-surgery training}

Confirmed or potential Covid-19 patients may experience feelings of loneliness, fear, anger, and anxiety before the operation due to both surgery and having an infectious disease. These emotional problems can be observed due to uncertainty, being in a different environment, leaving relatives behind, being alone, and fear of being disabled and dying. [12,14]. While approaching the patient, the feeling 
of trust should be established, taking this situation into consideration. Also, the patient's age, education level, and level of consciousness should be taken into consideration while communicating with the patient, and the patient's cultural values and beliefs should be respected [12].

The needs, priorities, developmental structure, experiences, and culture of the patient and the environmental conditions should be taken into consideration in patient education. Education should start as early as possible, taking these characteristics into account. However, there may be a time problem in emergency surgeries. For this reason, the patient should be informed shortly and in order of priority and should be given information about the structure of the operating room, the operating room staff, the intervention to be applied, the process, and the quarantine rules. If there is a situation such as emergency surgery that can be kept for 24-48 hours, preoperative training on breathing, coughing, early mobility, active body movements, foot exercises, and pain management should be planned [12]. The patient and his family should be told that there is a quarantine period of at least 14 days [1]. Information should be given on issues such as how to behave during this process, isolation rules, and hygiene. In addition, the patient should be informed that only the personnel responsible for the patient and who are required to enter will be allowed to enter the room and that there will be no patient visit [3].

If the patient's surgery is not very urgent and there is a period of 24-48 hours for the operation, it is also necessary to prepare for the patient's specific systems the night before. If the patient will undergo major abdominal, perianal, or perineal surgery, bowel preparation can be performed in accordance with institutional policy [12]. The preoperative fasting and carbohydrate treatment of the patient should be in accordance with the ERAS (Enchanged Recovery After Surgery) protocol [15].

For skin preparation, a general body bath is recommended in order to reduce the temporary flora of the patient. If the physician recommends, a skin antiseptic should be used during the bath. If hair removal is necessary, it should be performed in aseptic conditions and as soon as possible to begin the surgical procedure. If possible, electrical and skin-safe tools should be used for cleaning [12, 15]. In addition, the patient should be provided to spend the night before the surgery sleeping and comfortably [12].

\subsection{Legal preparation}

In the legal preparation phase, the patient should be informed about the forms specified in the hospital protocol (surgical procedure, blood transfusion, etc.), and signed consent must be obtained from the patient. These forms must be documented and included in the patient file [12]. Particular attention should be paid to the isolation methods during the signing of the Covid-19 patient. In fact, it is reported that verbal consent is sufficient in cases when there is a high probability of infection and that signed approval should not be obtained for security reasons [10].

\subsection{Transferring the patient to surgery}

On the day of the operation, it is checked whether everything that should be done before the surgery (patient's history, physical assessment, necessary diagnosis and laboratory tests, legal permission, informing the patient) has been performed completely [12]. Before transferring it to the operation, the patient's vital signs are checked and recorded (the materials used should be patientspecific) [10]. The clothes and removable prostheses (if any) of the patient are removed in a way that respects privacy. The patient is dressed in surgical clothes, bonnets, and overshoes. In order to ensure that the patient's skin color is monitored in the operation and the blood $\mathrm{O}_{2}$ is monitored with a pulse 
oximeter, the cosmetics on the nail should be removed, if any. Patient information and the presence of infectious disease and allergy should be written on the patient's wristband. The patient goes to the operating room, accompanied by a nurse on a wheelchair or stretcher [12]. During the transfer, the nurse should be wearing a PPE and the patient should be wearing a surgical mask. If the patient is receiving noninvasive or invasive breathing support, respiratory isolation measures should be followed and an N95 mask should be used instead of a surgical mask during the transfer. The nurse should deliver the records he/she received in accordance with the isolation methods and all the documents belonging to the patient to the operating room nurse [3].

Once the patient is transferred to the operating room, the nurse should remove the PPE. While removing the PPE, care should be taken to remove it in the correct order (gloves, gown, goggles, face protection, mask). In particular, it is necessary to remove the mask last and apply hand hygiene [3].

\section{Nursing Care During The Operation}

The surgical team assumes responsibility for the care of the patient upon taking the patient to the operating room. A well-organized surgical team reduces the risk of contamination through pathogens [16]. Among the most common causes of contamination of pathogens during surgery are accidents during the exchange of surgical instruments, and not wearing gloves, safety goggles, and mask during the procedure. It is also an important factor to have staff who do not have sufficient professional experience. When the personnel carrying medical wastes and doing cleaning duties neglect protective measures, there may be an infection [5].

$\mathrm{Ti}$ et al. presented an operating room protocol for confirmed or potential Covid-19 patients admitted to the hospital for surgery. They stated that in this protocol, an operating room with a negative pressure environment and a different entrance was arranged in one corner of the operating room complex and that the same anesthesia device was used only for Covid-19 patients during the pandemic [17]. It is controversial whether the surgical method to be applied to these patients should be performed with laparoscopic or open surgical methods. It has been revealed that there may be viruses in the surgical smoke produced during laparoscopy. It is recommended to use $\mathrm{CO}_{2}$ filters for aerosolized particles in laparoscopy $[10,18]$. In their study, Yu et al. suggested that the operations of patients with colon cancer infected with Covid-19 can be performed using the laparoscopic method by managing laparoscopic gase [18].

Nurses, who are the main advocates of the patient during the operation period, try to maintain the care, safety, and homeostasis of the patient. They inform the patient, give him/her the appropriate position, manage the pain and body temperature, and provide psychological support. They also try to provide a safe environment by defining the existing risk factors and supporting the solution of complex situations $[16,19]$. The sterile (scrab) nurse, who is responsible for the preparation of the operating room, works directly with the surgeon. Besides technical skills and dexterity, this nurse has knowledge of the anatomical and mechanical aspects of surgery $[1,20]$. The circulating nurse responsible for the management and coordination of the operating room accepts the patient to the operating room. This nurse helps the patient to be placed on the operating table, gives the correct position, cleans the skin for incision, and covers the patient. She/he ensures that the part(s) taken from the patient during pathology are sent to the pathology department. The circulating nurse also controls the application of aseptic techniques of scrup nurses and other team members $[16,21]$. In the operating room protocol, Ti et al. 
presented five interconnected rooms. Only the ante room and anesthesia induction rooms have negative atmospheric pressures [17]. In case additional medications or equipment are required during the operation, a runner is placed in the anteroom. These drugs and equipment are placed in a cart that is left in the ante room for the operating room team to take. The same process is employed in the reverse order to send samples such as arterial blood gas samples and frozen section samples. The runner wears PPE when entering the entrance room [17]. At the end of the operation, removing the PPE in a way that prevents contamination before leaving the operating room is one of the most important stages. At this stage, the team should move away from the patient with slow movements and should avoid contacting each other. They should help each other while removing the PPE and follow the principles of preventing basic contamination [3]. The personnel leaving the operating room throw their used gowns and gloves into the ante room and perform hand hygiene before leaving. All masks should be removed outside the ante room. When the operation is completed, at least one hour should be left between each case after the patient is sent to the ward. All personnel must take a shower before continuing their duties [17].

All disposable medical products and body fluids belonging to the operating period should be disposed of according to the medical waste standard; the operating room should be disinfected after surgery; and the infected person and the healthcare professionals entering the surgery should be isolated for 14 days $[10,19]$.

\section{Post-Operative Nursing Care}

In the postoperative period, which covers the time between patient's leaving the operating room and being discharged from the hospital, the aim is to reorganize the hemostatic balance of the patient, relieve his/her pain, prevent complications, ensure that the patient follows the self-care recommendations, and return to normal life in a short time [22-24].

\subsection{Care in the Postanesthesia Care Unit}

In the literature, if Covid-19 infected patients do not require intensive care, it is stated that they recover in the operating room, but there is uncertainty about the process of their admission to the Postanesthesia Care Unit (PACU) [10]. Under normal conditions, after the operation, the patient is taken to the PACU where care is given by specially trained nurses [22]. The PACU is located next to the operating room for fast patient transfer. After the operation, patients remain in this unit until the patient comes out of anesthesia and regain consciousness. Collaboration between anesthesiologists and PACU nurses is required in admitting patients to the PACU. The anesthetist is responsible for the transfer of the patient from the operating room to the PACU and checks the tools and equipment that should be kept in the PACU before the patient is transferred and completes what is missing [22-24]. While all patients should be kept in the PACU until their vital signs are stable after surgery, it is also known that patients who do not have a high risk of developing complications are taken directly to the clinic in many hospitals [24]. All the staff involved in the transfer and care process of Covid-19 patients should use PPE [17].

Nursing care in the PACU involves determining the patient's level of consciousness, location, time and person orientation, and response to verbal commands as well as controlling and observing respiratory and circulatory functions, pain, fever, bleeding, and drainage amount of the surgical site [22, 24]. After leaving the PACU, the patient can go to the intensive care unit or the clinic. The patient who 
does not need intensive care is transferred to the clinic by the PACU nurse and delivered to the clinical nurse [22].

\subsection{Care in the Surgical Clinic}

After the operation, the patient should be taken to the clinic in a single room, which is isolated from other units and where the patient stayed before having the operation, and visitors must be restricted to prevent cross-contamination $[10,18]$. It is recommended to include a chest diseases specialist and anesthesiologist in the patient's clinical treatment and care process. Specific treatment is not required in this direction in patients who do not have confirmed Covid-19 infection. Normal treatment and care are carried out. However, treatment and care specific to this virus is applied in patients with a definitive diagnosis of Covid-19 [10]. The same high performance is expected from nurses in patient care whether or not there is infection [25]. By taking the measures that follow the hospital protocol and ensure high levels of protection, nurses should provide the necessary nursing care. The standard nursing care of the patient who comes to the clinic after the operation involves evaluating respiration, monitoring of vital signs, observing the patient's skin, performing surgical wound dressing and drainage control, monitoring urinary catheter if any, evaluating urine amount and properties, preventing bladder distension, helping patients do deep breathing and coughing exercises. In addition, providing vessel and paper towels for nausea and vomiting, evaluating patient's level of consciousness, orientation, and limb mobility, assessing the severity of pain, giving an analgesic based on request and giving a safe and comfortable position, IV treatment control, and informing the patient and the family are involved in standard nursing care $[22,24]$.

\section{Discharge of the Patient}

After recovery due to surgery-related disease, patients who meet the discharge criteria for Covid19 can complete their recovery period at home. Within the scope of discharge training, information is given to the patient on wound care, dressing change, medications, activities, diet, symptoms, hygiene, and medical examination time. In the discharge applications for Covid-19, the patient is recorded in the system as 'follow-up at home'. The patient is given enough masks by the hospital. The patient should spend this time at home. Patients who are followed-up at home are examined by a family doctor until they recover. No visitors should be allowed to come home. If there are other people sharing the same house, the patient should wear a mask. The patient and his family are informed about hygiene, domestic isolation methods, emergency numbers, and the ways of monitoring health status and what to do [4, 22].

\section{Conclusion}

Studies are being conducted on the disease caused by Covid-19, which the World Health Organization has declared as a pandemic, and on the prevention methods. Furthermore, protocols and guidelines are being prepared. When the studies conducted so far were examined, it was seen that there are not enough studies on perioperative nursing care given in cases requiring urgent surgery. Nurses who spend more time with patients are at serious risk as they are at the forefront of the fight against Covid-19. For this reason, new studies on the perioperative care processes of Covid-19 infected patients are needed.

\section{Financial Support}

The authors declare that they have not received financial support for this review. 


\section{Conflict of Interest}

The authors declare that there are no conflicts of interest.

\section{References}

[1] Zhou, F., et al., "Clinical course and risk factors for mortality of adult inpatients with Covid-19 in Wuhan, China: a retrospective cohort study", Lancet, 395 (10229), 1054-1062, 2020. doi: 10.1016/S0140-6736(20)30566-3.

[2] Van Doremalen, N., et al., "Aerosol and Surface Stability of SARS-CoV-2 as Compared with SARS-CoV-1", N. Engl. J. Med., 382 (16),1564-1567, 2020. doi: 10.1056/NEJMc2004973.

[3] Kocaeli Üniversitesi, "Covid-19 hastalığı sağlı çalışanları vaka yönetim rehberi", 2020. http://tip.kocaeli.edu.tr/docs/Coronavirus-acileylemplani2020.pdf

[4] T.C. Ministry of Health, "Covid-19 (SARS-CoV-2 Enfeksiyonu) Rehberi", 2020. https://covid19bilgi.saglik.gov.tr/depo/rehberler/COVID-19_Rehberi.pdf

[5] Wen, X., Li, Y., "Letter to the editor anesthesia procedure of emergency operation for patients with suspected or confirmed Covid-19", Surgical Infections, 21(3), 1-2, 2020, doi: 10.1089/sur.2020.040.

[6] Chin, A.W.H., et al., "Stability of SARS- CoV- 2 in different environmental conditions", The Lancet Microbe, 1(1), e10, https://doi.org/10.1016/S2666-5247(20)30003-3

[7] T.C. Ministry of Health, "Türkiye günlük koronavirüs tablosu", 2020. https://covid19.saglik.gov.tr/

[8] Razai, M. S., Doerholt, K., et. al., "Coronavirus disease 2019 ( covid-19 ): a guide for UK", BMJ, 800, 1-5, 2020. doi: 10.1136/bmj.m800.

[9] Lu, R., et al., "Articles genomic characterisation and epidemiology of 2019 novel coronavirus : implications for virus origins and receptor binding", Lancet, 395(10224), 565-574, 2020. doi: 10.1016/S0140-6736(20)30251-8.

[10] Kamer, E., Çolak, T., "Covid-19 ile enfekte bir hastasının operasyona ihtiyacı olduğunda ne yapmalıyı: cerrahi öncesi, cerrahi sirası ve cerrahi sonrası rehberi what to do when a patient infected with covid-19 needs an operation", Turk J Color. Dis, 30, 1-8, 2020. doi: 10.4274/tjcd.galenos.2020.2020-3-7.

[11] Woldometer, "COVID-19 coronavirus pandemic", 2020. https://www.worldometers.info/coronavirus/?utm_campaign=homeAdvegas1?/embed/fd0k_hbX $\underline{\mathrm{WcQ}}$

[12] Aksoy, G., Ameliyat Öncesi Hemşirelik Bakımı, in: Cerrahi Hemşireliği 1, (Ed. Aksoy, G., Kanan, N., Akyolcu, N.,) Nobel tıp kitabevleri, İstanbul, pp. 257-300, 2017.

[13] Türk Hemşireler Derneği,“Covid-19 Hemşire Eğitim Rehberi ve Bakım Algoritmaları”, 2020. https://www.thder.org.tr/uploads/files/thd-covid-2020-2.pdf 
[14] Koray, B., "Covid-19 Salgınında psikiyatri: krize müdahale", 2020. https://www.psikiyatri.org.tr/2152/covid-19-salgininda-psikiyatri-krize-mudahale

[15] Dağıstanl1, S., Kalayc1, M. U., Kara, Y.,"Genel cerrahide eras protokolünün değerlendirilmesi, Evaluation of eras protocol in general surgery", IKSST Derg., 10, 9-20, 2018. doi: 10.5222/iksst.2018.43043.

[16] Nevin, K., Ameliyat sırası hemşirelik bakımı, in: Cerrahi Hemşireliği 1, (Ed. Akyolcu, N., Aksoy, G., Kanan N.,) Nobel Tip Kitabevleri, pp. 301-332, 2010.

[17] Ti, L.K., Lin,F., et al., "What we do when a Covid-19 patient needs an operation : operating room preparation and guidance", Can. J. Anesth. Can. d'anesthésie, 67, 19-21, 2020. doi: 10.1007/s12630-020-01617-4.

[18] Yu, G.Y., Lou, Z., Zhang, W., "[Several suggestions of operation for colorectal cancer under the outbreak of corona virus disease 2019 in China].", Zhonghua Wei Chang Wai Ke Za Zhi, 23 (3), 208-211, 2020. doi: 10.3760/cma.j.cn.441530-20200224-00074.

[19] Luo Y, Z.M., Wen, X., Li, Y.," Standardized diagnosis and treatment of colorectal cancer during the outbreak of novel coronavirus pneumonia in Renji hospital", Zhonghua Wei Chang Wai Ke Za Zhi, 23(3), E003, 2020. doi: 10.3760/cma.j.cn441530-20200217-00057.

[20] Çobanoğu, N., "Bireysel, profesyonel, toplumsal, bilimsel ve siyasal etiği yeniden sorgulatan Covid-19 pandemisi, Ethics of individual, professional, social, scientific and politic is questioned by COVID-19 pandemy", Anadolu Klin. Tip Bilim. Derg., 25 (1), 23-29, 2020. doi: 10.21673/anadoluklin.709891.

[21] Özbayır, T., Ameliyat Öncesi Bakım, in: Dahili ve Cerrahi Hastalıklarda Bakım, (Ed. Eti, Aslan, F., Karadakovan, A.,) Nobel Tip Kitabevleri, pp. 309-335, 2010.

[22] Eti, Aslan, F., Ameliyat Sonrası Bakım, in: Dahili ve Cerrahi Hastalıklarda Bakım, (Ed: Eti, Aslan, F., Karadakovan A.,) Nobel Kitabevi, pp. 345-372, 2010.

[23] Taşdemir, N., Ameliyat Sonrası Dönemde Hasta Bakımı, in: Güncel Yöntemlerle Cerrahi Hastalıklarda Bakım, (Ed. Taşdemir, N., Sevim, Ç.,), Çukurova Nobel Tıp Kitabevi, Antalya, pp. 76-91, 2018.

[24] Akyolcu, N., Ameliyat Sonrası Hemşirelik Bakımı, in: Cerrahi Hemşireliği 1, (Ed. Akyolcu, N., Aksoy, G., Nevin, K.,) Nobel Tip Kitabevleri, pp. 335-366, 2012.

[25] R. Choi, K., Jeffers, K. S., "Nursing and the novel coronavirus: risks and responsibilities in a global outbreak", J. Adv. Nurs., 76(7), 1-2, 2020. doi: 10.1111/jan.14369. 